\title{
Microstructure and Mechanical Properties of Novel Quasibinary Al-Cu-Yb and Al-Cu-Gd Alloys
}

\author{
Sayed Amer ${ }^{1,2}$, Ruslan Barkov ${ }^{1}$ and Andrey Pozdniakov ${ }^{1, *}$ \\ 1 Department of Physical Metallurgy of Non-Ferrous Metals, National University of Science and Technology \\ "MISIS", Leninskiy pr. 4, 119049 Moscow, Russia; e.khamees@misis.ru (S.A.); barkov@misis.ru (R.B.) \\ 2 Mining, Metallurgy and Petroleum Engineering Department, Faculty of Engineering, Al-Azhar University, \\ Cairo 11884, Egypt \\ * Correspondence: pozdniakov@misis.ru; Tel.: +7-(495)-638-44-80
}

Citation: Amer, S.; Barkov, R.; Pozdniakov, A. Microstructure and Mechanical Properties of Novel Quasibinary $\mathrm{Al}-\mathrm{Cu}-\mathrm{Yb}$ and $\mathrm{Al}-\mathrm{Cu}-\mathrm{Gd}$ Alloys. Metals 2021, 11, 476. https://doi.org/10.3390/met11030476

Academic Editor: Marcello Cabibbo

Received: 19 February 2021

Accepted: 10 March 2021

Published: 13 March 2021

Publisher's Note: MDPI stays neutral with regard to jurisdictional claims in published maps and institutional affiliations.

Copyright: (c) 2021 by the authors. Licensee MDPI, Basel, Switzerland. This article is an open access article distributed under the terms and conditions of the Creative Commons Attribution (CC BY) license (https:// creativecommons.org/licenses/by/ $4.0 /)$.

\begin{abstract}
Microstructure of Al-Cu-Yb and Al-Cu-Gd alloys at casting, hot-rolled -cold-rolled and annealed state were observed; the effect of annealing on the microstructure was studied, as were the mechanical properties and forming properties of the alloys, and the mechanism of action was explored. Analysis of the solidification process showed that the primary Al solidification is followed by the eutectic reaction. The second $\mathrm{Al}_{8} \mathrm{Cu}_{4} \mathrm{Yb}$ and $\mathrm{Al}_{8} \mathrm{Cu}_{4} \mathrm{Gd}$ phases play an important role as recrystallization inhibitor. $\mathrm{The}^{\mathrm{Al}_{3}} \mathrm{Yb}$ or $(\mathrm{Al}, \mathrm{Cu})_{17} \mathrm{Yb}_{2}$ phase inclusions are present in the $\mathrm{Al}-\mathrm{Cu}-\mathrm{Yb}$ alloy at the boundary between the eutectic and aluminum dendrites. The recrystallization starting temperature of the alloys is in the range of $250-350{ }^{\circ} \mathrm{C}$ after rolling with previous quenching at 590 and $605^{\circ} \mathrm{C}$ for $\mathrm{Al}-\mathrm{Cu}-\mathrm{Yb}$ and $\mathrm{Al}-\mathrm{Cu}-\mathrm{Gd}$, respectively. The hardness and tensile properties of $\mathrm{Al}-\mathrm{Cu}-\mathrm{Yb}$ and $\mathrm{Al}-\mathrm{Cu}-\mathrm{Gd}$ as-rolled alloys are reduced by increasing the annealing temperature and time. The as-rolled alloys have high mechanical properties: YS $=303 \mathrm{MPa}$, UTS $=327 \mathrm{MPa}$ and El. $=3.2 \%$ for Al-Cu-Yb alloy, while YS = $290 \mathrm{MPa}$, UTS = $315 \mathrm{MPa}$ and El.$=2.1 \%$ for Al-Cu-Gd alloy.
\end{abstract}

Keywords: aluminum alloys; ytterbium; gadolinium; quasi-binary alloys; mechanical properties

\section{Introduction}

Al- $\mathrm{Cu}$ alloy is an important series of aluminum alloys, because of its excellent properties, such as high specific strength, etc. 2xxx series aluminum alloys with copper has been widely used in many applications such as aerospace and automotive industries [1-7]. Due to low weight, high strength and excellent machinability, $\mathrm{Al}-\mathrm{Cu}$ alloys are important candidates for steel substitution in some applications in the aerospace and automotive industries [8]. Currently, it is imperative to further improve the strength and stiffness of lightweight alloys to develop the next generation of aircraft and vehicles [8-10]. Rare earth elements have been added in aluminum alloys to improve the tensile strength, heat resistance and corrosion resistance [11,12]. For example, when $\mathrm{Sc}$ was added into $\mathrm{Al}$ alloys, a thermo-stable $\mathrm{L}_{2}$-type $\left(\mathrm{AuCu}_{3}\right) \mathrm{Al}_{3} \mathrm{Sc}$ phase would form in the $\mathrm{Al}$ solid solution, which was able to inhibit the re-crystallization and the grain growth and then significantly improve the high temperature properties of the alloys $[13,14]$. A similar to the addition of $\mathrm{Sc}$, a $\mathrm{L1}_{2}$-type $\left(\mathrm{AuCu}_{3}\right)$ phase $\mathrm{Al}_{3} \mathrm{Yb}$ formed when $\mathrm{Yb}$ was added into $\mathrm{Al}$ alloys [15]. It was found that after partial replacement of $\mathrm{Sc}$ with either $\mathrm{Yb}$ or $\mathrm{Gd}$, the mechanical properties, such as incubation time and peak hardness of the $\mathrm{Al}$ alloy were improved [16]. The recrystallization process of the $\mathrm{Al}-\mathrm{Cu}-\mathrm{Mn}$ alloy can be greatly slowed by the addition of Gd [17].

The influence of rare earth elements is not only in improving mechanical properties by producing new second phases, but also through improving casting defects. For example, Min et al. [18] studied the effect of $Y$ content on the hot-tearing resistance in $\mathrm{Al}-5 \mathrm{wt} . \% \mathrm{Cu}$ based alloys, and it was found that precipitation of the Y-rich phase increased the resistance of hot-tearing and reduced the susceptibility of hot rupture significantly. Addition of $\mathrm{Zr}$ to 
Al-Cu-Re alloys also improves mechanical properties of $\mathrm{Al}-\mathrm{Cu}$ alloys due to precipitation of the $\mathrm{Al}_{3}(\mathrm{RE}, \mathrm{Zr})$ phase [19-21]. Most importantly, the addition of $\mathrm{Mn}$ to Al-Cu-Y [22] and Al-Cu-Er [23] induces a new quaternary phase precipitation $(\mathrm{Al}, \mathrm{Cu}, \mathrm{Mn}, \mathrm{Y} / \mathrm{Er})$ with possible composition $\mathrm{Al}_{25} \mathrm{Cu}_{4} \mathrm{Mn}_{2} \mathrm{Y} / \mathrm{Er}$.

Many researchers studied the possibility of using quasi-binary alloys of the Al-Cu-RE system to develop novel Al casting alloys with significantly improved casting properties compared to commercial 2xx alloys. The quasi-binary alloys of Al-Cu-Ce [24,25], Al-Cu$\mathrm{Y}[26-28]$ and Al-Cu-Er [26,29,30] with an atomic ratio of $4 / 1(\mathrm{Cu} / \mathrm{RE})$ is an interesting research due to the precipitation of the $\mathrm{Al}_{8} \mathrm{Cu}_{4} \mathrm{RE}$ phase, which leads to an improvement in the mechanical properties of these alloys. This quasi-binary eutectic has a fine microstructure and is capable of fragmentation and spheroidization during heating. The rare earth elements $\mathrm{Yb}$ and $\mathrm{Gd}$ can play a better role than these elements. In the following work, we will study effect of $\mathrm{Zr}, \mathrm{Mn}$, and other alloying elements on $\mathrm{Al}-\mathrm{Cu}-\mathrm{Yb}$ and $\mathrm{Al}-\mathrm{Cu}-\mathrm{Gd}$ alloys. These may provide better mechanical properties to these alloys, which helps in discovering novel alloys that can be used in various industries.

In this work, the microstructure and mechanical properties of the novel $\mathrm{Al}-\mathrm{Cu}-\mathrm{Yb}$ and Al-Cu-Gd alloys were studied. Efforts have been made to understand the mechanism responsible for improving the structure and properties of Al-Cu alloy by the addition of the rare earth elements $\mathrm{Yb}$ and $\mathrm{Gd}$. As-cast, homogenized microstructure was investigated. Evaluation of the mechanical properties after thermo-mechanical treatment was analyzed. The alloys may be prospective for the development of novel heat-resistant materials for the aerospace industry due to the high thermal stability of the eutectic phases, and may be used as a cast and wrought base alloy due to a wide solidification range and tensile strength. To increase its mechanical properties, the investigated alloy can be additionally alloyed with $\mathrm{Zr}, \mathrm{Mn}$, and Mg. Due to its good castability, the alloy is a promising material for use in additive manufacturing by laser selective melting.

\section{Materials and Methods}

The alloys that used in this study were Al-Cu-Yb and Al-Cu-Gd. The raw materials for casting were pure $\mathrm{Al}(99.99 \%)$ and master alloys of $\mathrm{Al}-52 \mathrm{Cu}, \mathrm{Al}-10 \mathrm{Yb}$ and $\mathrm{Al}-10 \mathrm{Gd}$. Master alloys were melted using by Al (99.99\%). The alloys were prepared in a graphite crucible in an electric resistance furnace, poured into a cast copper mold, and water cooled to ambient temperature. The dimensions are $120 \mathrm{~mm} \times 40 \mathrm{~mm} \times 20 \mathrm{~mm}$. The cooling rate was about $15 \mathrm{Ks}^{-1}$. The nominal composition of the alloys in the present study has been shown in Table 1.

Table 1. Chemical composition of the alloys, wt \%.

\begin{tabular}{ccccc}
\hline Alloys & $\mathbf{C u}$ & Yb & Gd & Al \\
\hline $\mathrm{Al}-\mathrm{Cu}-\mathrm{Yb}$ & 4.4 & 2.5 & - & bal. \\
\hline $\mathrm{Al}-\mathrm{Cu}-\mathrm{Gd}$ & 4.5 & - & 2.5 & bal. \\
\hline
\end{tabular}

The as-cast ingots of Al-Cu-Yb and Al-Cu-Gd were homogenized at 590 and $605{ }^{\circ} \mathrm{C}$, respectively, for 1,3 and $6 \mathrm{~h}$ and then quenched in water. The ingots were hot-rolled to $10 \mathrm{~mm}$ at $440{ }^{\circ} \mathrm{C}$, then cold-rolled to $1 \mathrm{~mm}$. Then, the alloys were annealed at 150, 180, $210^{\circ} \mathrm{C}$ for $0.5,1,2,3$ and $6 \mathrm{~h}$ and at $100-600$ for $1 \mathrm{~h}$ (Figure 1 ). The microstructures were characterized using scanning electron microscopy (SEM) Tescan-VEGA 3LMH (Tescan Brno s.r.o., Kohoutovice, Czech Republic) and Axiovert 200 MMAT (Carl Zeiss, Oberkochen, Germany) optical light microscope (LM). X-ray diffraction (XRD) data were collected with the $\mathrm{Cu}-\mathrm{K} \alpha$ radiation on a Bruker D8 Advance diffractometer (Bruker, Karlsruheб, Germany) to identify specific phases in the produced alloys. Labsys Setaram differential scanning calorimeter (DSC) (SETARAM Instrumentation, Caluire, France) was used to determine the liquidus and solidus temperatures. Nabertherm furnace (Nabertherm, Lilienthal, Germany) with an accuracy about $1 \mathrm{~K}$ was used to homogenize the as-cast ingot. The Vickers hardness measurements were performed with a load $5 \mathrm{KgF}$ and a dwell time of $10 \mathrm{~s}$. The tensile tests 
were carried out using a Zwick/Roell Z250 Allround series testing machine (Zwick/Roell, Kennesaw, GA, USA). The tensile test specimens were cut out from $1 \mathrm{~mm}$ thick rolled sheets. A total of three tensile samples of each alloy were prepared and tested, and the average of these three data was acted as the re-ported result. The gage length and width of the samples were 20 and $6 \mathrm{~mm}$, respectively (Figure 1). The strain rate was $4 \mathrm{~mm} \mathrm{~min}^{-1}$. Ultimate tensile strength (UTS), yield strength (YS) and elongation (El.) to failure were measured.

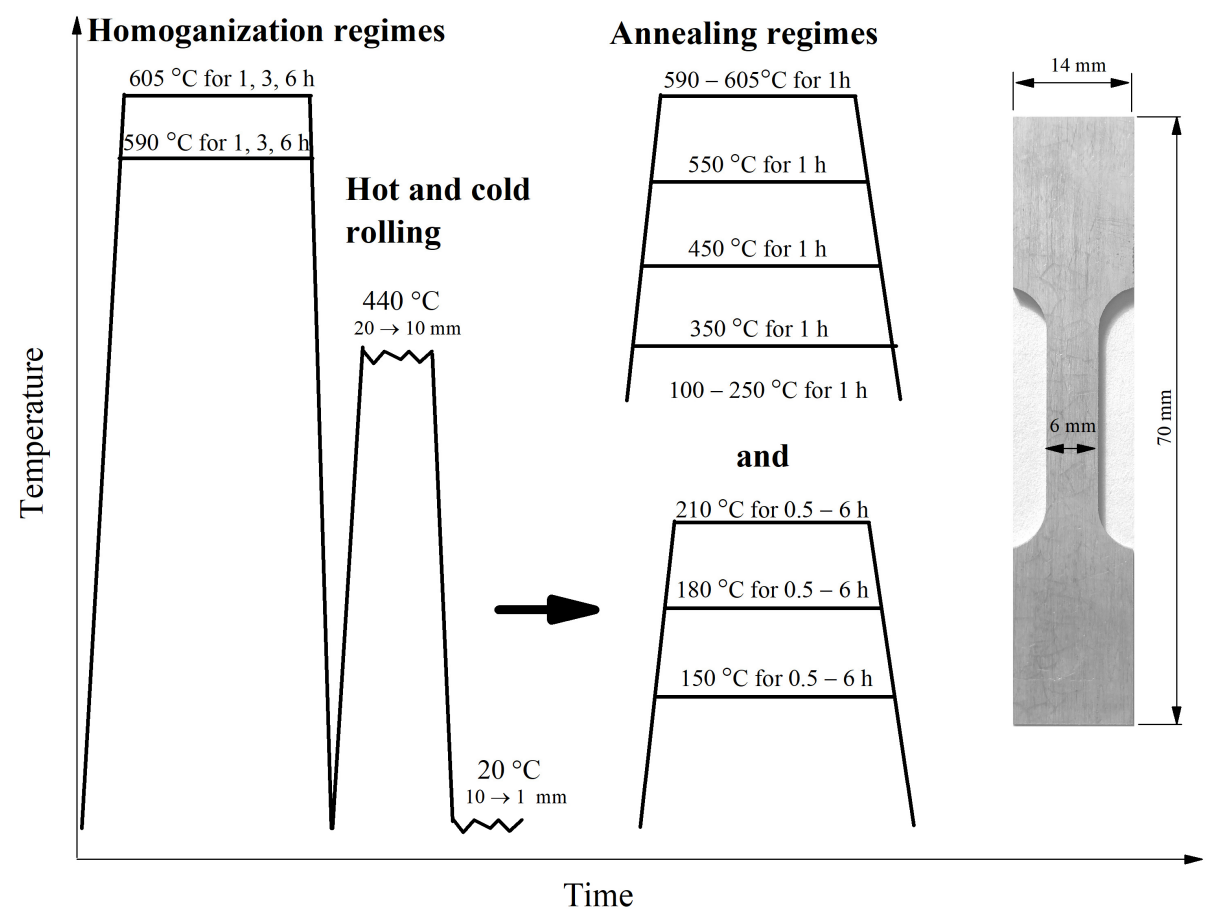

Figure 1. Scheme of the thermo-mechanical treatment of the alloys and tensile test sample.

\section{Results and Discussion}

This section should provide a concise and precise description of the experimental results, their interpretation, as well as the experimental conclusions that can be drawn. Figure 2 shows the microstructure of as-cast alloys of both Al-Cu-Yb and Al-Cu-Gd at different magnifications. The as-cast microstructure of $\mathrm{Al}-\mathrm{Cu}-\mathrm{Yb}$ (Figure 2a) is represented by aluminum solid solution, dispersed eutectic and bright inclusions, meanwhile the ascast microstructure of Al-Cu-Gd (Figure $2 \mathrm{~b}$ ) is represented by aluminum solid solution and dispersed eutectic. The four $(\mathrm{AlCu})_{12} \mathrm{Yb}\left(\tau_{1}\right),\left(\mathrm{Al}_{0.47} \mathrm{Cu}_{0.53}\right)_{17} \mathrm{Yb}_{2}\left(\tau_{2}\right), \mathrm{Al}_{2} \mathrm{Cu}$ and $\mathrm{Al}_{3} \mathrm{Yb}$ phases may be in equilibrium with aluminum solid-solution in to the $\mathrm{Al}$ region accordingly ternary phase diagram [15]. The dispersed eutectic of $\mathrm{Al}-\mathrm{Cu}-\mathrm{Yb}$ consists of aluminum solid solution and $(\mathrm{AlCu})_{12} \mathrm{Yb}$. Bright inclusions in $\mathrm{Al}-\mathrm{Cu}-\mathrm{Yb}$ are present at the boundaries between the eutectic and the aluminum dendrites of either $\mathrm{Al}_{3} \mathrm{Yb}$ or $(\mathrm{Al}, \mathrm{Cu})_{17} \mathrm{Yb}_{2}$ phase. Into the ternary $\mathrm{Al}-\mathrm{Cu}-\mathrm{Gd}$ phase diagram in the equilibrium with aluminum solid-solution presented $\mathrm{Al}_{8} \mathrm{Cu}_{4} \mathrm{Gd}\left(\tau_{1}\right), \mathrm{Al}_{3.2} \mathrm{Cu}_{7.8} \mathrm{Gd}\left(\tau_{2}\right), \mathrm{Al}_{2} \mathrm{Cu}$ and $\mathrm{Al}_{3} \mathrm{Gd}$ phases [17]. The dispersed eutectic in $\mathrm{Al}-\mathrm{Cu}-\mathrm{Gd}$ alloy consists of aluminum solid solution and $\mathrm{Al}_{8} \mathrm{Cu}_{4} \mathrm{Gd}$ phases. 

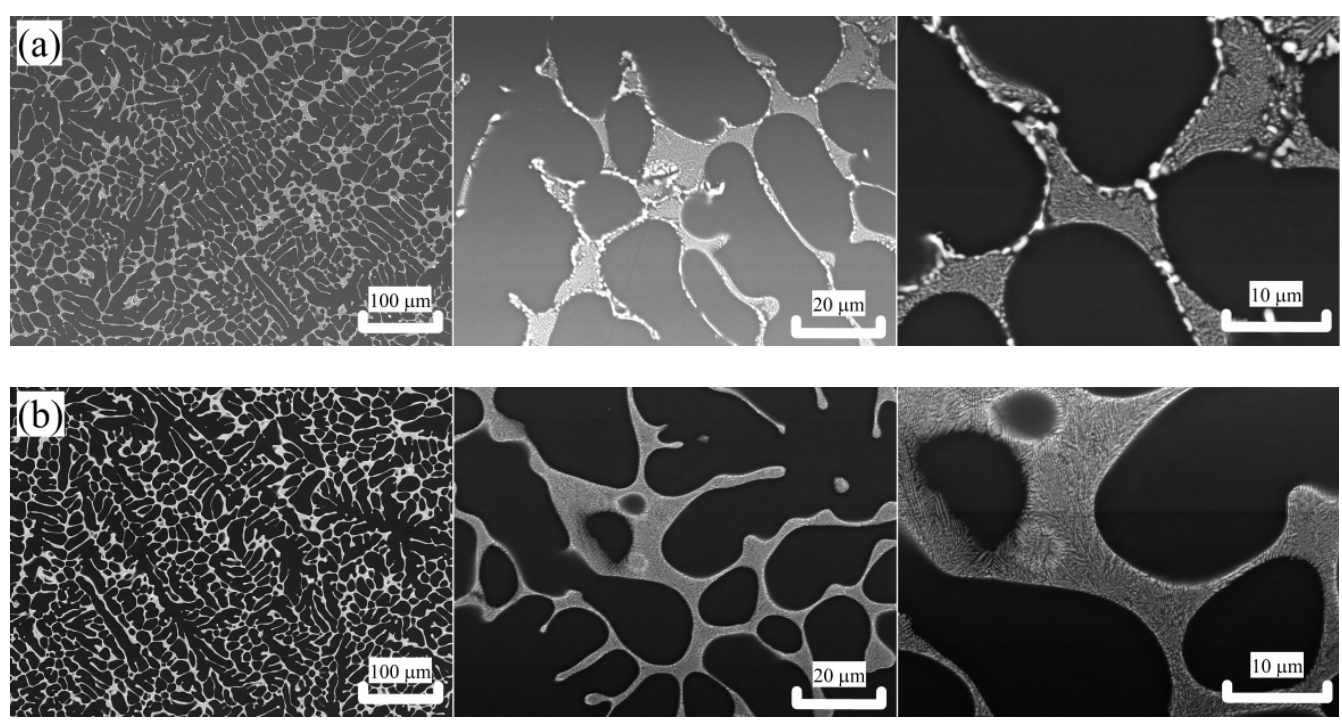

Figure 2. As cast microstructure of the $\mathrm{Al}-\mathrm{Cu}-\mathrm{Yb}(\mathbf{a})$ and $\mathrm{Al}-\mathrm{Cu}-\mathrm{Gd}(\mathbf{b})$ alloys at different magnification.

Figure 3 displays the XRD patterns of as-cast $\mathrm{Al}-\mathrm{Cu}-\mathrm{Yb}$ and $\mathrm{Al}-\mathrm{Cu}-\mathrm{Gd}$ alloys in compare with the Al-Cu-Er [29] and Al-Cu-Y [27] alloys phase composition. XRD analysis of $\mathrm{Al}-\mathrm{Cu}-\mathrm{Yb}$ and $\mathrm{Al}-\mathrm{Cu}-\mathrm{Gd}$ alloys reveals peaks for aluminum and $\mathrm{Al}_{8} \mathrm{Cu}_{4} \mathrm{X}$ similar to those of Al-Cu-Er and Al-Cu-Y alloys. The most part of the peaks in the alloys in the same angle corresponds of the $\mathrm{Al}_{8} \mathrm{Cu}_{4} \mathrm{X}$ phase, where $\mathrm{X}$ is $\mathrm{Yb}, \mathrm{Gd}, \mathrm{Er}$, or $\mathrm{Y}$. These peaks rounded by green oval in the Figure 3. This phase improved the mechanical properties of Al-Cu alloys, as for the Al-Cu-Y and Al-Cu-Er alloys. Comparison of the literature data [15] and obtained results allows to conclude that the $(\mathrm{AlCu})_{12} \mathrm{Yb}\left(\tau_{1}\right)$ phase in the Al-Cu-Yb alloy corresponds of the $\mathrm{Al}_{8} \mathrm{Cu}_{4} \mathrm{Yb}$ phase.

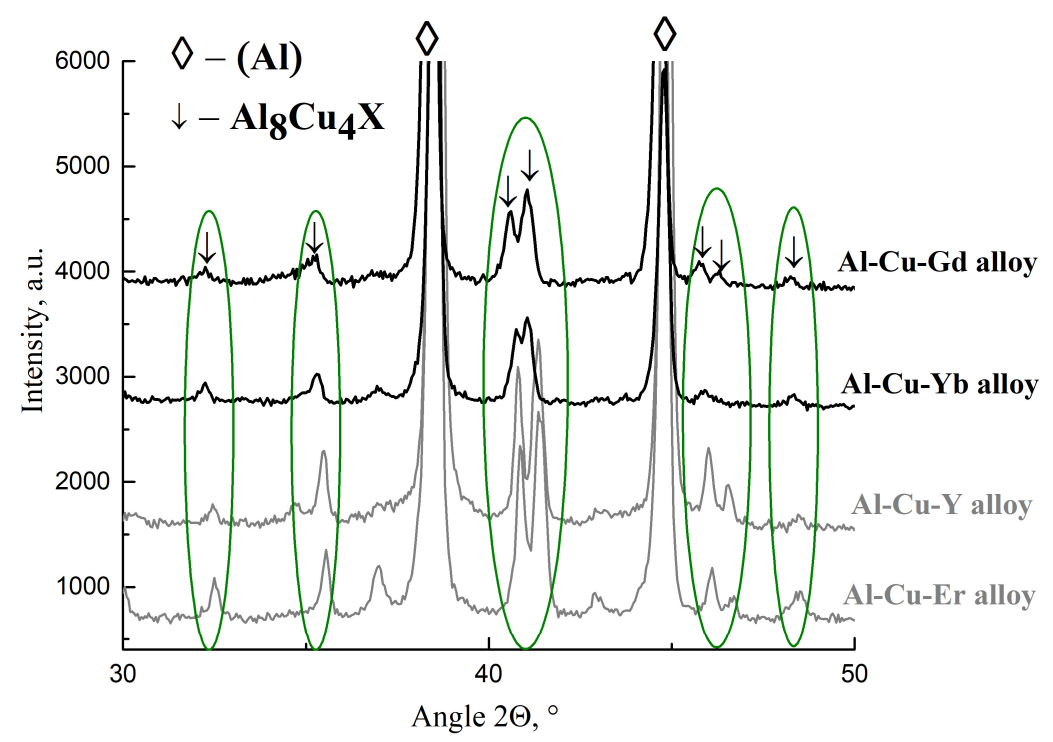

Figure 3. XRD-patterns of the Al-Cu-Yb and Al-Cu-Gd alloys in compare with the Al-Cu-Er [29] and Al-Cu-Y [27] alloys.

The DSC analysis showed that the liquidus and solidus temperatures for the Al-Cu$\mathrm{Yb}$ alloy are 635 and $600{ }^{\circ} \mathrm{C}$, respectively (Figure $4 \mathrm{a}$ ), while for the Al-Cu-Gd alloy are 634 and $615^{\circ} \mathrm{C}$, respectively (Figure $4 \mathrm{~b}$ ). The solidus temperature was determined on the cooling curve (bottom curve) and the liquidus temperature on the heating curve (upper curve). The solidification range of the alloy is about $20-35^{\circ} \mathrm{C}$. The wide solidification range should provide a good castability. In accordance with the solidus temperatures of 
alloys, the temperature of 590 and $605^{\circ} \mathrm{C}$ were selected as the homogenization temperature before quenching for $\mathrm{Al}-\mathrm{Cu}-\mathrm{Yb}$ and $\mathrm{Al}-\mathrm{Cu}-\mathrm{Gd}$ alloys, respectively. Figure 5 illustrates the SEM microstructures of the Al-Cu-Yb and Al-Cu-Gd alloys after homogenization at 590 and $605{ }^{\circ} \mathrm{C}$ for 1,3 and $6 \mathrm{~h}$ with subsequent water quenching. It can be seen that during homogenization, there take place processes of fragmentation, spheroidization, and growth of the $\mathrm{Al}_{8} \mathrm{Cu}_{4} \mathrm{Yb}$ and $\mathrm{Al}_{8} \mathrm{Cu}_{4} \mathrm{Gd}$ eutectic phases. The size of $\mathrm{Al}_{8} \mathrm{Cu}_{4} \mathrm{Yb}$ and $\mathrm{Al}_{8} \mathrm{Cu}_{4} \mathrm{Gd}$ phases increased from $0.25-0.3$ to $1.8-2.4 \mu \mathrm{m}$ (measured by random secant method) after homogenization to $6 \mathrm{~h}$. The copper concentration in the solid solution increases from 1.1-1.3 in the as-cast state to $1.7 \%$ (point SEM analyze) in both $\mathrm{Al}-\mathrm{Cu}-\mathrm{Yb}$ and $\mathrm{Al}-\mathrm{Cu}-\mathrm{Gd}$ alloys after $3 \mathrm{~h}$ of annealing and remains unchanged as the annealing time increases to $6 \mathrm{~h}$. Figure 6 illustrates the changes of the intermetallic phase particle size and the concentration of the copper in the aluminum solid solution depends on the homogenization time.
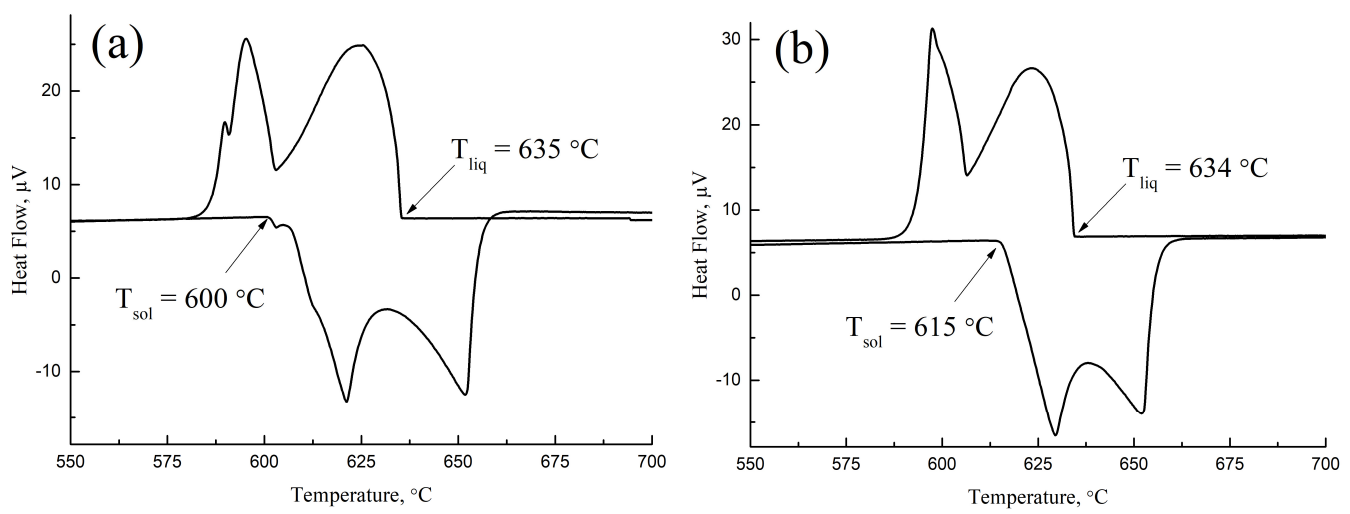

Figure 4. DSC-curves of the $\mathrm{Al}-\mathrm{Cu}-\mathrm{Yb}(\mathbf{a})$ and $\mathrm{Al}-\mathrm{Cu}-\mathrm{Gd}(\mathbf{b})$ alloys.
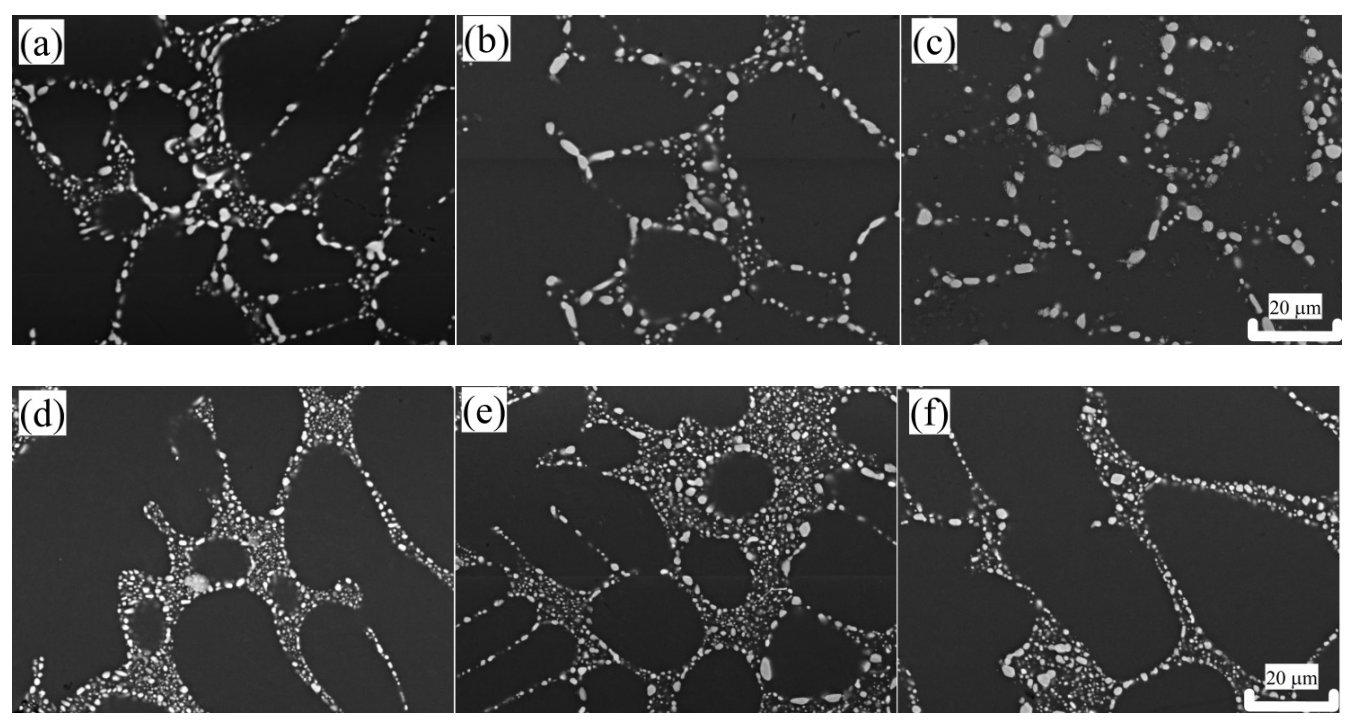

Figure 5. Microstructure evaluation of the $\mathrm{Al}-\mathrm{Cu}-\mathrm{Yb}(\mathbf{a}-\mathbf{c})$ and $\mathrm{Al}-\mathrm{Cu}-\mathrm{Gd}(\mathbf{d}-\mathbf{f})$ alloys after homogenization treatment for $1 \mathrm{~h}$ $(\mathbf{a}, \mathbf{d}), 3 \mathrm{~h}(\mathbf{b}, \mathbf{e})$ and $6 \mathrm{~h}(\mathbf{c}, \mathbf{f})$.

Figure 7 shows the hardness of the rolled alloys at different annealing temperatures 150, 180 and $210^{\circ} \mathrm{C}$ for $0.5,1,2,3$ and $6 \mathrm{~h}$ (Figure $7 \mathrm{a}, \mathrm{b}$ ). The results showed that the hardness of $\mathrm{Al}-\mathrm{Cu}-\mathrm{Yb}$ and $\mathrm{Al}-\mathrm{Cu}-\mathrm{Gd}$ alloys decreased with increasing annealing temperature and time, this may be attributed to the decrease in dislocation density, and formation of subgrains. On the other hand, the hardness of the $\mathrm{Al}-\mathrm{Cu}-\mathrm{Yb}$ rolled alloy was higher than that of Al-Cu-Gd in the same case of annealing temperatures and time. This may be 
attributed to the presence of either the $\mathrm{Al}_{3} \mathrm{Yb}$ or $(\mathrm{Al}, \mathrm{Cu})_{17} \mathrm{Yb}_{2}$ phase, which increased the alloy's mechanical properties.

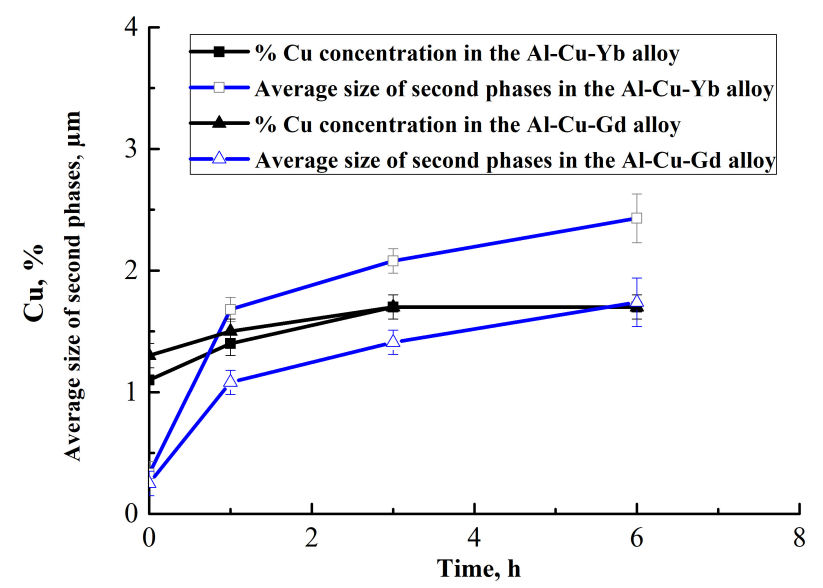

Figure 6. Average size of second phases and copper concentration in the solid solution depends on the homogenization time.
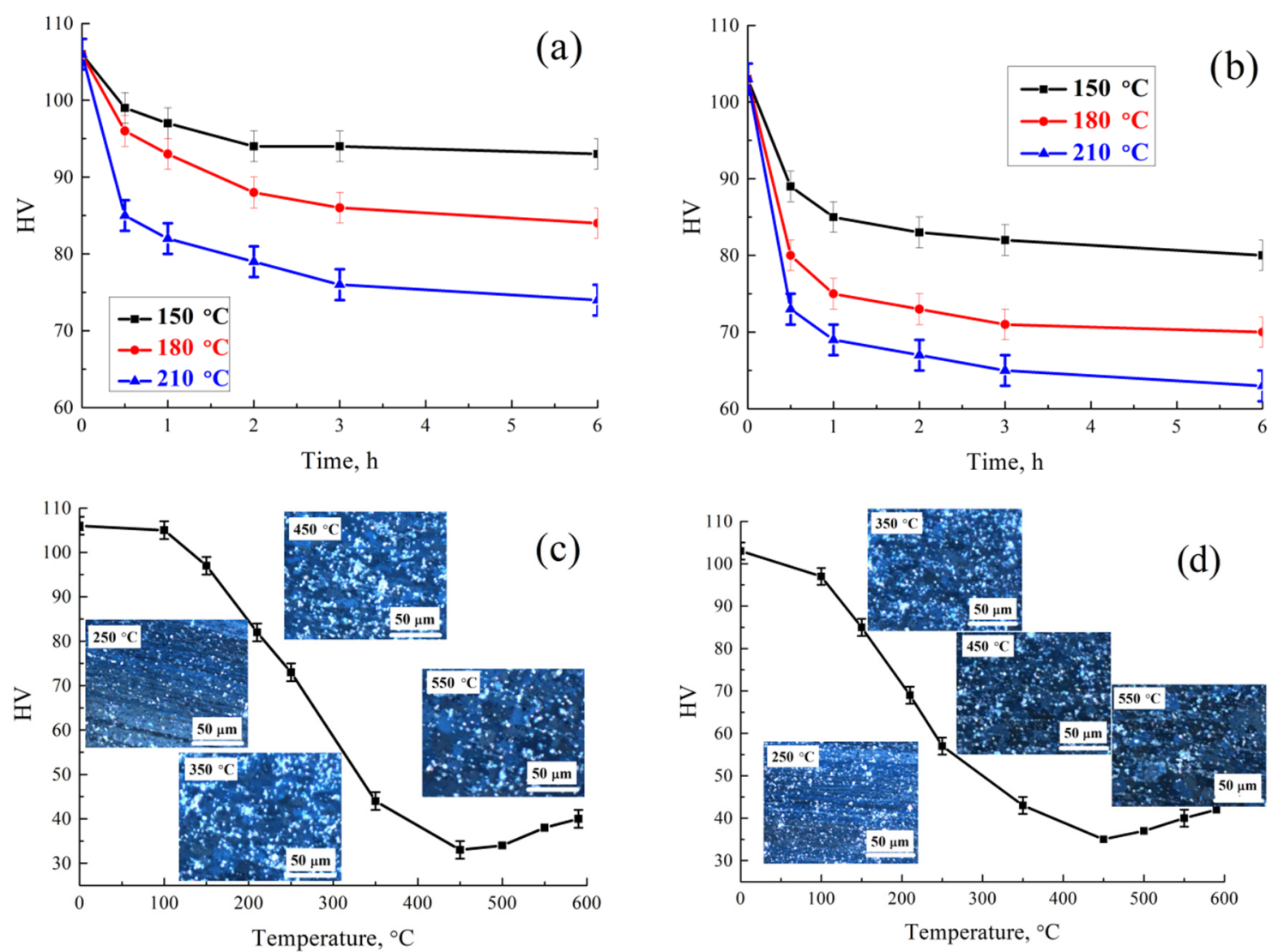

Figure 7. HV vs. time $(\mathbf{a}, \mathbf{b})$ and temperature $(1 \mathrm{~h})(\mathbf{c}, \mathbf{d})$ dependencies of the rolled $\mathrm{Al}-\mathrm{Cu}-\mathrm{Yb}(\mathbf{a}, \mathbf{c})$ and Al-Cu-Gd $(\mathbf{b}, \mathbf{d})$ alloys (inserts in $\mathrm{c}$ and $\mathrm{d}$-grain structure after annealing at indicated temperature).

Inserts in the Figure 7a,b and Figure 8 show the grain structure of $\mathrm{Al}-\mathrm{Cu}-\mathrm{Yb}$ and Al-Cu-Gd alloys with different temperature. The microstructure of the alloys at different annealing temperatures was observed and the results were consistent with the hardness test results. Regarding the alloys at $250{ }^{\circ} \mathrm{C}$, the microstructure is still fiber shaped rolling deformation; when the annealing temperature is $350^{\circ} \mathrm{C}$, the alloys began recrystallization, 
and when the annealing temperature increased to $450^{\circ} \mathrm{C}$, the alloy has basically completed the recrystallization. The hardness of the deformed alloy decreased due to the occurrence of static recovery and recrystallization. With an increase in the annealing temperature to $450{ }^{\circ} \mathrm{C}$, the same restoration processes in the matrix, as well as an increase in the precipitate sizes, led to an intensive decrease in the alloy hardness in both alloys. At annealing temperatures exceeding $450{ }^{\circ} \mathrm{C}$ (above the solvus point), the alloy matrix was usually saturated with the elements of the main alloys according to the phase diagram, and again led to the formation of a supersaturated solid solution, accompanied by repeated hardening of the alloying solution led to increase the hardness [31]. The average grain size of $\mathrm{Al}-\mathrm{Cu}-\mathrm{Yb}$ and Al-Cu-Gd alloy increased from $8 \mu \mathrm{m}$ after annealing at $350{ }^{\circ} \mathrm{C}$ for $1 \mathrm{~h}$ to $12 \mu \mathrm{m}$ at $550{ }^{\circ} \mathrm{C}$.

Table 2 and Figure 9 show that the mechanical tensile properties of $\mathrm{Al}-\mathrm{Cu}-\mathrm{Yb}$ and Al-Cu-Gd alloys reduce by increasing the annealing temperature and time. The results were consistent with those of the hardness test. On the other hand, Al-Cu-Yb alloy has higher mechanical tensile properties than Al-Cu-Gd, but the elongation of Al-Cu-Gd alloy after annealing at $250{ }^{\circ} \mathrm{C}(16 \%)$ is higher than that of $\mathrm{Al}-\mathrm{Cu}-\mathrm{Yb}(6 \%)$. Moreover, the $\mathrm{Al}-\mathrm{Cu}-\mathrm{Yb}$ rolled-alloy has higher mechanical properties than Al-Cu-Y [26,27] alloy, especially after annealing at $150{ }^{\circ} \mathrm{C}$ for $3 \mathrm{~h}$. The as-rolled alloys mechanical tensile properties $\left(150{ }^{\circ} \mathrm{C}, 3 \mathrm{~h}\right)$ : $\mathrm{YS}=272 \mathrm{MPa}$, UTS= $294 \mathrm{MPa}$ and El. $=5.6 \%$ for $\mathrm{Al}-\mathrm{Cu}-\mathrm{Yb}$ alloy, while $\mathrm{YS}=254 \mathrm{MPa}$, $\mathrm{UTS}=273 \mathrm{MPa}$ and El. $=2.2 \%$ for Al-Cu-Y alloy, and $\mathrm{YS}=267 \mathrm{MPa}, \mathrm{UTS}=289 \mathrm{MPa}$ and El. $=2.8 \%$ for Al-Cu-Er alloy [26].
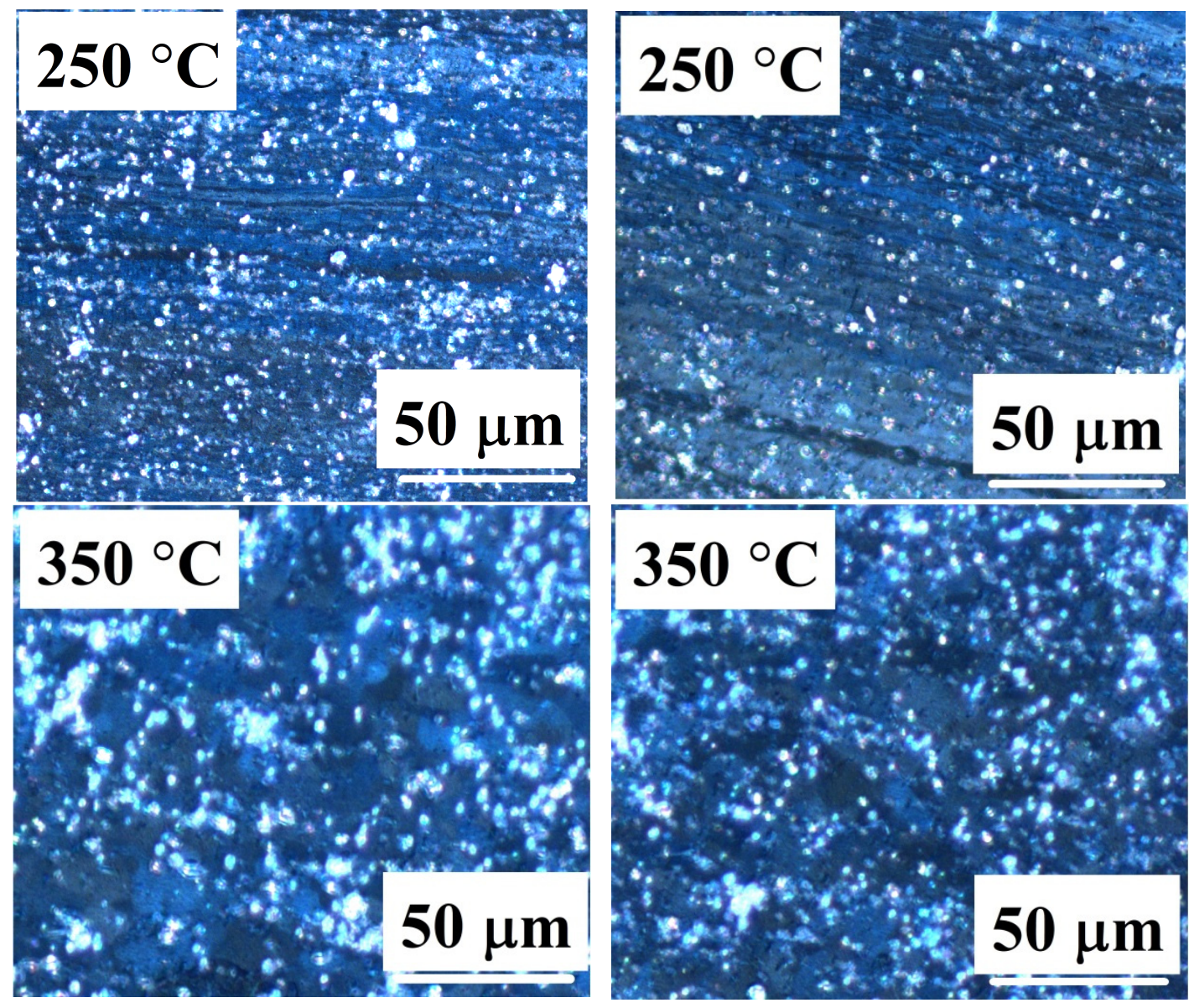

Figure 8. Cont. 


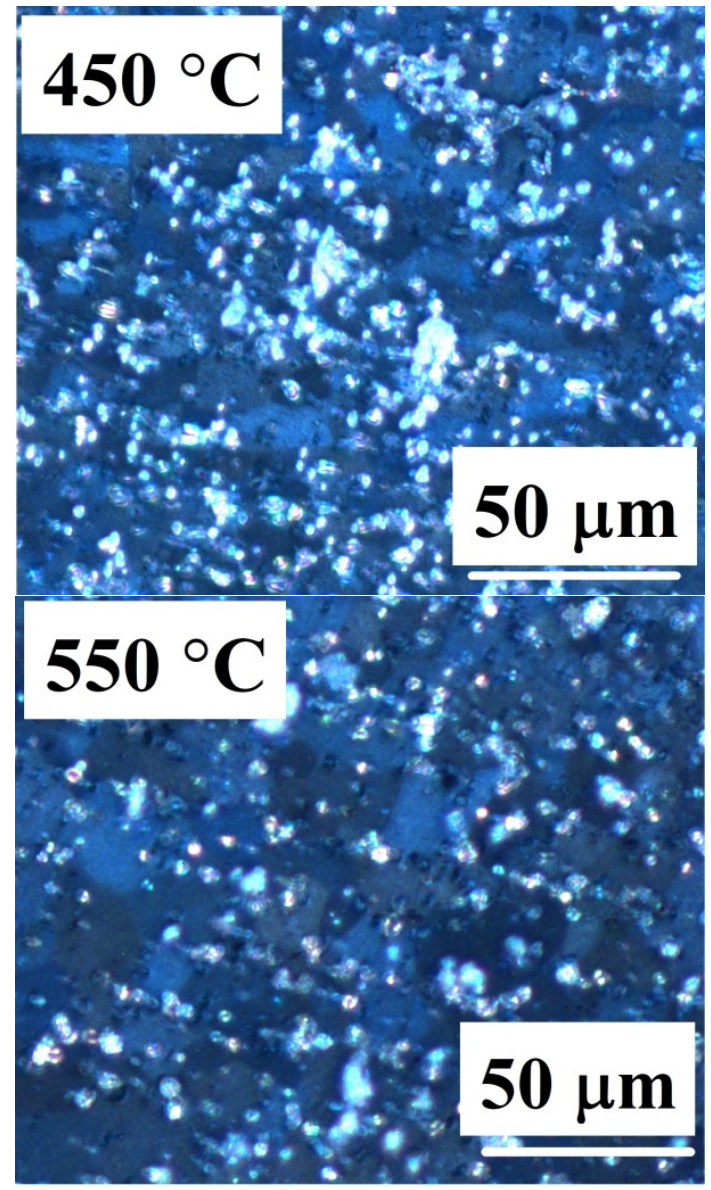

$\mathrm{Al}-\mathrm{Cu}-\mathrm{Yb}$ alloy

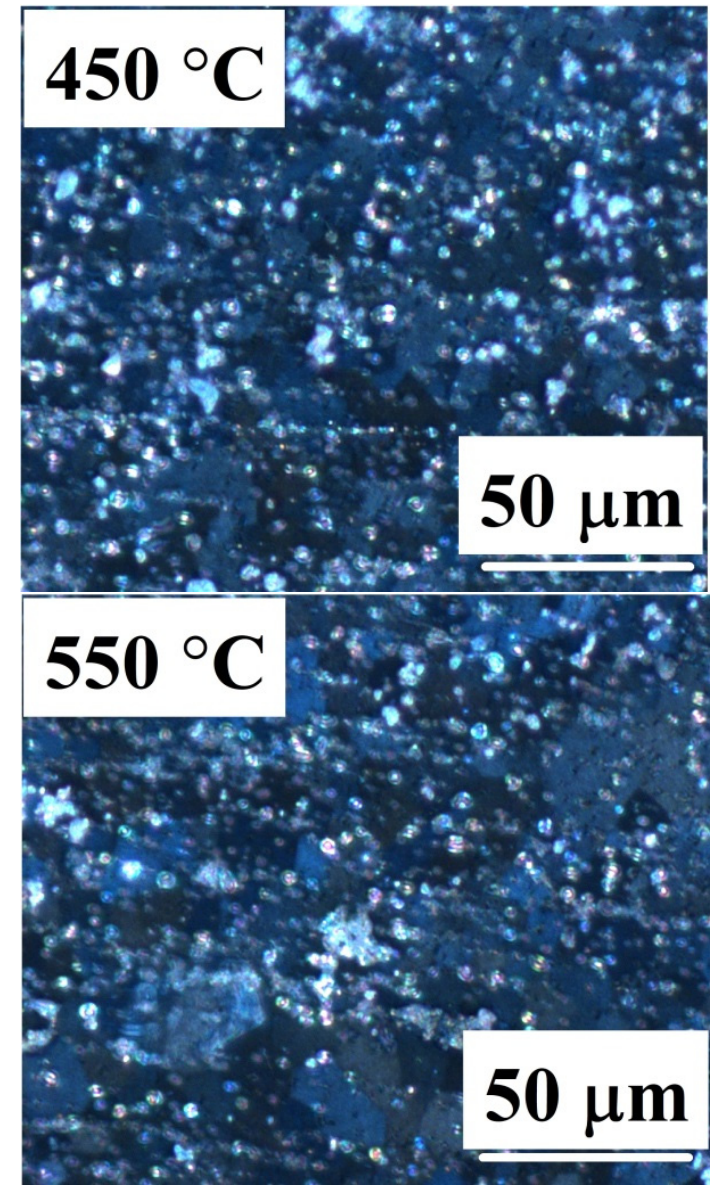

Al-Cu-Gd alloy

Figure 8. Grain structure of the investigated alloys in the annealed at $250-550{ }^{\circ} \mathrm{C}$ for $1 \mathrm{~h}$ after rolling conditions.
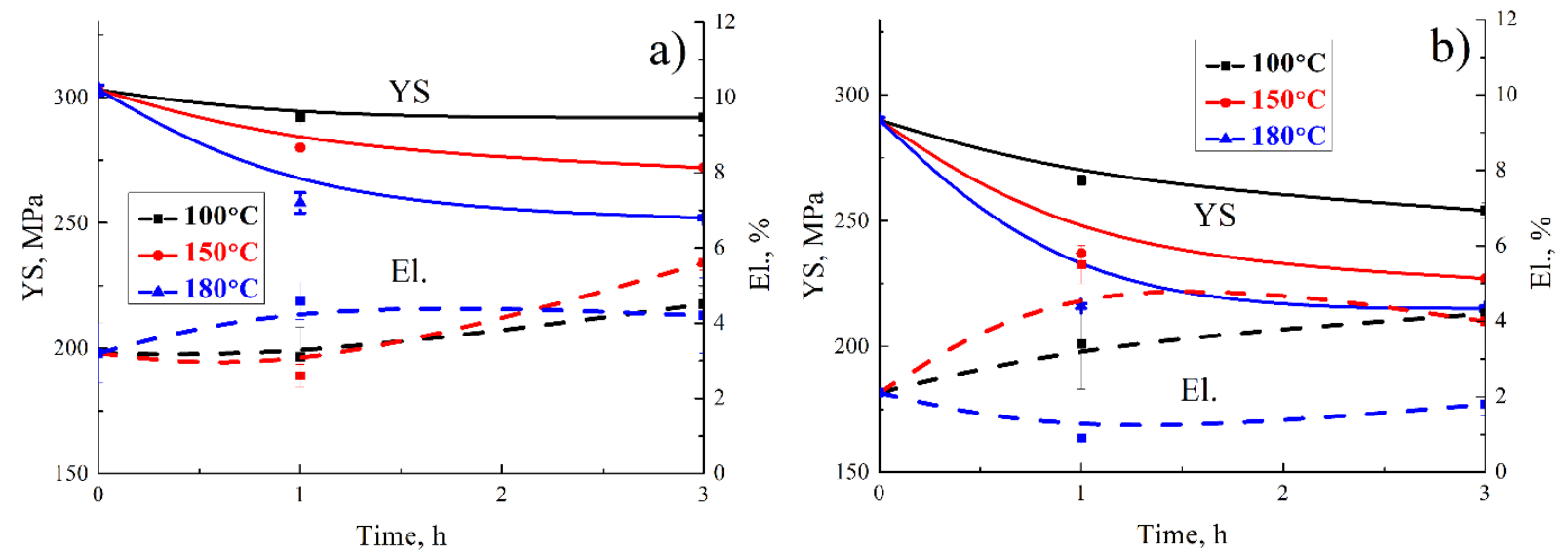

Figure 9. YS and El. dependencies vs. time after annealing at 100,150 and $180{ }^{\circ} \mathrm{C}$ for the (a) $\mathrm{Al}-\mathrm{Cu}-\mathrm{Yb}$ and (b) $\mathrm{Al}-\mathrm{Cu}-$ Gd alloys. 
Table 2. Tensile properties of the Al-Cu-Yb and Al-Cu-Gd alloys in the as rolled and annealed states.

\begin{tabular}{cccc}
\hline State & YS, MPa & UTS, MPa & El., \% \\
\hline \multicolumn{2}{c}{ As rolled } & Al-Cu-Yb & $3.2 \pm 0.8$ \\
\hline Annealed at $100^{\circ} \mathrm{C}$ for $1 \mathrm{~h}$ & $303 \pm 2$ & $327 \pm 2$ & $3.1 \pm 0.8$ \\
Annealed at $100^{\circ} \mathrm{C}$ for $3 \mathrm{~h}$ & $292 \pm 3$ & $319 \pm 3$ & $4.5 \pm 0.3$ \\
Annealed at $150^{\circ} \mathrm{C}$ for $1 \mathrm{~h}$ & $292 \pm 4$ & $318 \pm 4$ & $2.6 \pm 0.3$ \\
Annealed at $150^{\circ} \mathrm{C}$ for $3 \mathrm{~h}$ & $280 \pm 1$ & $303 \pm 1$ & $5.6 \pm 0.2$ \\
Annealed at $180^{\circ} \mathrm{C}$ for $1 \mathrm{~h}$ & $272 \pm 2$ & $294 \pm 3$ & $4.6 \pm 0.5$ \\
Annealed at $180^{\circ} \mathrm{C}$ for $3 \mathrm{~h}$ & $258 \pm 4$ & $276 \pm 2$ & $4.2 \pm 1.0$ \\
Annealed at $210^{\circ} \mathrm{C}$ for $1 \mathrm{~h}$ & $252 \pm 1$ & $268 \pm 1$ & $5.9 \pm 0.1$ \\
Annealed at $250^{\circ} \mathrm{C}$ for $0.5 \mathrm{~h}$ & $238 \pm 2$ & $253 \pm 1$ & $6 \pm 2$ \\
\hline & $216 \pm 2$ & $229 \pm 1$ & \\
\hline As rolled & & & $2.1 \pm 0.1$ \\
\hline Annealed at $100^{\circ} \mathrm{C}$ for $1 \mathrm{~h}$ & $\mathrm{Al}-\mathrm{Cu}-\mathrm{Gd}$ & $315 \pm 2$ & $3.4 \pm 1.2$ \\
Annealed at $100^{\circ} \mathrm{C}$ for $3 \mathrm{~h}$ & & $285 \pm 3$ & $4.2 \pm 0.6$ \\
Annealed at $150^{\circ} \mathrm{C}$ for $1 \mathrm{~h}$ & $290 \pm 1$ & $278 \pm 4$ & $5.5 \pm 0.5$ \\
Annealed at $150^{\circ} \mathrm{C}$ for $3 \mathrm{~h}$ & $266 \pm 2$ & $253 \pm 1$ & $4.0 \pm 1.0$ \\
Annealed at $180^{\circ} \mathrm{C}$ for $1 \mathrm{~h}$ & $254 \pm 3$ & $244 \pm 2$ & $0.9 \pm 0.1$ \\
Annealed at $180^{\circ} \mathrm{C}$ for $3 \mathrm{~h}$ & $237 \pm 2$ & $226 \pm 1$ & $1.8 \pm 0.3$ \\
Annealed at $210^{\circ} \mathrm{C}$ for $1 \mathrm{~h}$ & $227 \pm 2$ & $225 \pm 2$ & $6.7 \pm 0.7$ \\
Annealed at $250^{\circ} \mathrm{C}$ for $0.5 \mathrm{~h}$ & $216 \pm 1$ & $210 \pm 1$ & $16.0 \pm 1.2$ \\
\hline
\end{tabular}

\section{Conclusions}

1. The microstructure and mechanical properties of $\mathrm{Al}-4.4 \mathrm{Cu}-2.5 \mathrm{Yb}$ and $\mathrm{Al}-4.5 \mathrm{Cu}-2.5 \mathrm{Gd}$ alloys were investigated. The microstructure revealed the presence of the aluminum solid solution and $\mathrm{Al}_{8} \mathrm{Cu}_{4} \mathrm{Yb}$ and $\mathrm{Al}_{8} \mathrm{Cu}_{4} \mathrm{Gd}$ phases, which play an important role as recrystallization inhibitor. These also phases improved the mechanical properties of $\mathrm{Al}-\mathrm{Cu}$ alloys. $\mathrm{Al}_{3} \mathrm{Yb}$ or $(\mathrm{Al}, \mathrm{Cu})_{17} \mathrm{Y}_{2}$ phase was found in addition in the $\mathrm{Al}-\mathrm{Cu}-\mathrm{Yb}$ alloy at the boundary between the eutectic and aluminum dendrites.

2. The size of $\mathrm{Al}_{8} \mathrm{Cu}_{4} \mathrm{Yb}$ and $\mathrm{Al}_{8} \mathrm{Cu}_{4} \mathrm{Gd}$ phases increased from 0.25-0.3 to 1.8-2.4 $\mu \mathrm{m}$ after homogenization at 590 and $605{ }^{\circ} \mathrm{C}$ for $6 \mathrm{~h}$. The $\mathrm{Al}_{8} \mathrm{Cu}_{4} \mathrm{Yb}$ and $\mathrm{Al}_{8} \mathrm{Cu}_{4} \mathrm{Gd}$ phases demonstrate a good thermal stability at high temperature homogenization treatment.

3. By increasing the annealing temperature and time after rolling, the hardness and tensile properties of rolled alloys $\mathrm{Al}-4.4 \mathrm{Cu}-2.5 \mathrm{Yb}$ and $\mathrm{Al}-4.5 \mathrm{Cu}-2.5 \mathrm{Gd}$ are reduced. The mechanical properties of the $\mathrm{Al}-\mathrm{Cu}-\mathrm{Yb}$ rolled alloy were higher than that of $\mathrm{Al}-\mathrm{Cu}-\mathrm{Gd}, \mathrm{Al}-\mathrm{Cu}-\mathrm{Y}$ and $\mathrm{Al}-\mathrm{Cu}-\mathrm{Er}$ in the same case of annealing temperatures and time. This may be attributed to the presence of either $\mathrm{Al}_{3} \mathrm{Yb}$ or $(\mathrm{Al}, \mathrm{Cu})_{17} \mathrm{Y}_{2}$ phase, which increased the alloy's mechanical properties.

4. The as-rolled and annealed at $150{ }^{\circ} \mathrm{C}$ for $3 \mathrm{~h}$ alloys mechanical tensile properties: $\mathrm{YS}=272 \mathrm{MPa}, \mathrm{UTS}=294 \mathrm{MPa}$ and $\mathrm{El} .=5.6 \%$ for $\mathrm{Al}-\mathrm{Cu}-\mathrm{Yb}$ alloy, while $\mathrm{YS}=227 \mathrm{MPa}$, UTS $=244 \mathrm{MPa}$ and El. $=2.2 \%$ for Al-Cu-Gd alloy.

5. The alloys may be a prospective for the development of novel heat-resistant materials for the aerospace industry due to the high thermal stability of the eutectic phases and may be used as a cast and wrought base alloy due to a wide solidification range and tensile strength.

Author Contributions: Data curation, S.A., R.B. and A.P.; formal analysis, S.A.; investigation, R.B.; methodology, R.B. and A.P.; project administration, A.P.; visualization, A.P.; writing-original draft preparation, S.A. and A.P.; writing-review and editing, A.P. All authors have read and agreed to the published version of the manuscript.

Funding: The work was carried out with the support of the Ministry of Science and Higher Education of the Russian Federation in the framework of the State Task (project code 0718-2020-0030). 
Institutional Review Board Statement: Not applicable.

Informed Consent Statement: Not applicable.

Data Availability Statement: Not applicable.

Acknowledgments: S. M. Amer gratefully acknowledge the financial support of the Ministry of Education and Science of the Russian Federation in the framework of Increase Competitiveness Program of MISiS.

Conflicts of Interest: The authors declare that there are no conflict of interest.

\section{References}

1. Chen, X.; Zhan, L.; Ma, Z.; Xu, Y.; Zheng, Q.; Cai, Y. Study on tensile/compressive asymmetry in creep ageing behavior of Al-Cu alloy under different stress levels. J. Alloys Compd. 2020, 843, 156157. [CrossRef]

2. Yang, Y.; Zhan, L.; Liu, C.; Wang, X.; Wang, Q.; Tang, Z.; Li, G.; Huang, M.; Hu, Z. Stress-relaxation ageing behavior and microstructural evolution under varying initial stresses in an $\mathrm{Al}-\mathrm{Cu}$ alloy: Experiments and modeling. Int. J. Plast. 2020, 127, 102646. [CrossRef]

3. He, H.; Yi, Y.; Huang, S.; Zhang, Y. Effects of cold predeformation on dissolution of second-phase Al2Cu particles during solution treatment of $2219 \mathrm{Al}-\mathrm{Cu}$ alloy forgings. Mater. Charact. 2018, 135, 18-24. [CrossRef]

4. Inforzato, D.J.; Costa, P.R.; Fernandez, F.F.; Travessa, D.N. Creep-age forming of AA7475 aluminum panels for aircraft lower wing skin application. Mater. Res. 2012, 15, 596-602. [CrossRef]

5. Wang, H.; Yi, Y.; Huang, S. Microstructure Evolution and Mechanical Properties of 2219 Al Alloy During Aging Treatment. J. Mater. Eng. Perform. 2017, 26, 1475-1482. [CrossRef]

6. Meng, F.; Wang, Z.; Zhao, Y.; Zhang, D.; Zhang, W. Microstructures and properties evolution of Al-Cu-Mn alloy with addition of vanadium. Metals 2017, 7, 10. [CrossRef]

7. Belov, N.A.; Avksent'eva, N.N. Quantitative analysis of the Al-Cu-Mg-Mn-Si phase diagram as applied to commercial aluminum alloys of series 2xxx. Met. Sci. Heat Treat. 2013, 55, 358-363. [CrossRef]

8. Matvienko, Y.I.; Polishchuk, S.S.; Rud, A.D.; Popov, O.Y.; Demchenkov, S.A.; Fesenko, O.M. Effect of graphite additives on microstructure and mechanical properties of Al-Cu composites prepared by mechanical alloying and sintering. Mater. Chem. Phys. 2020, 254, 123437. [CrossRef]

9. Immarigeon, J.P.; Holt, R.T.; Koul, A.K.; Zhao, L.; Wallace, W.; Beddoes, J.C. Lightweight materials for aircraft applications. Mater. Charact. 1995, 35, 41-67. [CrossRef]

10. Witik, R.A.; Payet, J.; Michaud, V.; Ludwig, C.; Månson, J.A.E. Assessing the life cycle costs and environmental performance of lightweight materials in automobile applications. Compos. Part A Appl. Sci. Manuf. 2011, 42, 1694-1709. [CrossRef]

11. Zhang, L.; Masset, P.J.; Cao, F.; Meng, F.; Liu, L.; Jin, Z. Phase relationships in the Al-rich region of the Al-Cu-Er system. J. Alloys Compd. 2011, 509, 3822-3831. [CrossRef]

12. Zhang, L.G.; Liu, L.B.; Huang, G.X.; Qi, H.Y.; Jia, B.R.; Jin, Z.P. Thermodynamic assessment of the Al-Cu-Er system. Calphad Comput. Coupling Phase Diagr. Thermochem. 2008, 32, 527-534. [CrossRef]

13. Li, Q.; Zhang, Y.; Lan, Y.; Zhang, Y.; Xia, T. The effect of Sc addition on the novel nano-AlCu phase in as-cast Al-5\%Cu alloy. J. Alloys Compd. 2020, 831, 154739. [CrossRef]

14. Gao, Y.H.; Kuang, J.; Zhang, J.Y.; Liu, G.; Sun, J. Tailoring precipitation strategy to optimize microstructural evolution, aging hardening and creep resistance in an Al-Cu-Sc alloy by isochronal aging. Mater. Sci. Eng. A 2020, 795, 139943. [CrossRef]

15. Huang, G.; Liu, L.; Zhang, L.; Jin, Z. Thermodynamic description of the al-cu-yb ternary system supported by first-principles calculations. J. Min. Metall. Sect. B Metall. 2016, 52, 177-183. [CrossRef]

16. Karnesky, R.A.; van Dalen, M.E.; Dunand, D.C.; Seidman, D.N. Effects of substituting rare-earth elements for scandium in a precipitation-strengthened Al-0.08 at. \%Sc alloy. Scr. Mater. 2006, 55, 437-440. [CrossRef]

17. Zhang, L.G.; Dong, H.Q.; Huang, G.X.; Shan, J.; Liu, L.B.; Jin, Z.P. Thermodynamic assessment of the Al-Cu-Gd system. Calphad Comput. Coupling Phase Diagr. Thermochem. 2009, 33, 664-672. [CrossRef]

18. Li, M.; Wang, H.; Wei, Z.; Zhu, Z. The effect of $\mathrm{Y}$ on the hot-tearing resistance of Al-5 wt.\% Cu based alloy. Mater. Des. 2010, 31, 2483-2487. [CrossRef]

19. Amer, S.M.; Yu Barkov, R.; Yakovtseva, O.A.; Loginova, I.S.; Pozdniakov, A.V. Effect of Zr on microstructure and mechanical properties of the Al-Cu-Er alloy. Mater. Sci. Technol. 2020, 36, 453-459. [CrossRef]

20. Rouxel, B.; Ramajayam, M.; Langan, T.J.; Lamb, J.; Sanders, P.G.; Dorin, T. Effect of dislocations, Al3(Sc,Zr) distribution and ageing temperature on $\theta^{\prime}$ precipitation in Al-Cu-(Sc)-(Zr) alloys. Materialia 2020, 9, 100610. [CrossRef]

21. Pozdniakov, A.V.; Barkov, R.Y.; Amer, S.M.; Levchenko, V.S.; Kotov, A.D.; Mikhaylovskaya, A.V. Microstructure, mechanical properties and superplasticity of the Al-Cu-Y-Zr alloy. Mater. Sci. Eng. A 2019, 758, 28-35. [CrossRef]

22. Amer, S.M.; Barkov, R.Y.; Pozdniakov, A.V. Effect of Mn on the Phase Composition and Properties of Al-Cu-Y-Zr Alloy. Phys. Met. Metallogr. 2020, 121, 1227-1232. [CrossRef] 
23. Amer, S.; Yakovtseva, O.; Loginova, I.; Medvedeva, S.; Prosviryakov, A.; Bazlov, A.; Barkov, R.; Pozdniakov, A. The Phase Composition and Mechanical Properties of the Novel Precipitation-Strengthening Al-Cu-Er-Mn-Zr Alloy. Appl. Sci. 2020, 10, 5345. [CrossRef]

24. Belov, N.A.; Khvan, A.V. The ternary Al-Ce-Cu phase diagram in the aluminum-rich corner. Acta Mater. 2007, 55, 5473-5482. [CrossRef]

25. Belov, N.A.; Khvan, A.V.; Alabin, A.N. Microstructure and Phase Composition of Al-Ce-Cu Alloys in the Al-Rich Corner. Mater. Sci. Forum 2006, 519-521, 395-400. [CrossRef]

26. Amer, S.M.; Barkov, R.Y.; Yakovtseva, O.A.; Pozdniakov, A.V. Comparative Analysis of Structure and Properties of Quasibinary Al-6.5Cu-2.3Y and Al-6Cu-4.05Er Alloys. Phys. Met. Metallogr. 2020, 121, 476-482. [CrossRef]

27. Pozdniakov, A.V.; Barkov, R.Y. Microstructure and materials characterisation of the novel Al-Cu-Y alloy. Mater. Sci. Technol. 2018, 34, 1489-1496. [CrossRef]

28. Amer, S.M.; Barkov, R.Y.; Pozdniakov, A.V. Effect of Iron and Silicon Impurities on Phase Composition and Mechanical Properties of Al-6.3Cu-3.2Y Alloy. Phys. Met. Metallogr. 2020, 121, 1002-1007. [CrossRef]

29. Pozdnyakov, A.V.; Barkov, R.Y.; Sarsenbaev, Z.; Amer, S.M.; Prosviryakov, A.S. Evolution of Microstructure and Mechanical Properties of a New Al-Cu-Er Wrought Alloy. Phys. Met. Metallogr. 2019, 120, 614-619. [CrossRef]

30. Amer, S.M.; Barkov, R.Y.; Pozdniakov, A.V. Effect of Impurities on the Phase Composition and Properties of a Wrought Al-6\% $\mathrm{Cu}-4.05 \%$ Er Alloy. Phys. Met. Metallogr. 2020, 121, 495-499. [CrossRef]

31. Ilyasov, R.R.; Avtokratova, E.V.; Krymskiy, S.V.; Sitdikov, O.S.; Markushev, M.V. Effect of preliminary heterogenization on the structure and hardness of cryorolled aluminum alloy D16. IOP Conf. Ser. Mater. Sci. Eng. 2018, 447, 012047. [CrossRef] 